\title{
Rancang Bangun Aplikasi Perangkat Bergerak Layanan Pemesanan Barang (Studi Kasus "Dinas Kebersihan dan Pertamanan Kota Surabaya")
}

\author{
Shoffi Izza Sabilla, Sarwosri, dan Erma Suryani \\ Jurusan Teknik Informatika, Fakultas Teknologi Informasi, Institut Teknologi Sepuluh Nopember (ITS) \\ Jl. Arief Rahman Hakim, Surabaya 60111 Indonesia \\ e-mail: sarwosri@if.its.ac.id
}

\begin{abstract}
Abstrak - Layanan pemesanan barang di Dinas Kebersihan dan Pertamanan Kota Surabaya saat ini masih menggunakan cara manual. Petugas lapangan harus mendatangi kantor Dinas Kebersihan dan Pertamanan untuk melakukan pemesanan barang. Membutuhkan waktu yang lama untuk melakukan pemesanan barang, proses bisnis menjadi tidak efisien. Untuk menyelesaikan permasalahan tersebut dilakukan pembuatan aplikasi dengan perangkat bergerak. Aplikasi ini nantinya akan digunakan petugas lapangan untuk melakukan pemesanan barang sehingga tidak perlu datang ke kantor Dinas Kebersihan dan Pertamanan Kota Surabaya. Pada tahap pengujian dilakukan dengan melakukan pemesanan barang dan manajemen data pemesanan secara runtut. Proses pengiriman dan penerimaan data untuk melakukan pemesanan barang serta melihat status pemesanan juga diuji. Hasil dari pengujian yang telah dilakukan, aplikasi layanan pemesanan barang menjadi solusi terhadap permasalahan pemesanan barang yang kurang efektif. Hal ini berdasarkan dengan hasil kuisioner yang telah dilakukan dengan jawaban $60 \%$ sangat setuju dan $40 \%$ setuju.
\end{abstract}

Kata Kunci-Android, Pemesanan, Perangkat Bergerak

\section{PENDAHULUAN}

$\mathrm{S}$ URABAYA adalah kota terbesar di Jawa Timur, sudah pasti akan selalu mengupayakan proses pembangunan untuk meningkatkan kesejahteraan masyarakatnya. Dalam pembangunan Kota Surabaya, pemerintah Kota Surabaya dibantu oleh beberapa dinas pemerintah yang memiliki ranah kerja yang berbeda-beda. Terdapat 27 dinas di Kota Surabaya salah satunya adalah Dinas Kebersihan dan Pertamanan. Salah satu fungsi pokok Dinas Kebersihan dan Pertamanan Kota Surabaya adalah, pelaksanaan fasilitasi dalam pengelolaan kebersihan, pertamanan, penerangan jalan umum dan dekorasi kota, pemakaman, pembibitan, pengolahan sampah, air limbah rumah tangga dan lumpur tinja. Akan tetapi di Surabaya masih banyak tempat-tempat pembuangan sampah yang salah penempatannya atau sudah tidak memadai lagi. Kota Surabaya memiliki dinas yang menangani permasalahan kebersihan dan taman kota yaitu Dinas Kebersihan dan Pertamanan.

Saat ini, layanan pemesanan barang untuk mengganti kerusakan fasilitas kota seperti gerobak sampah masih menggunakan cara manual yaitu petugas harus mendatangi kantor Dinas Kebersihan dan Pertamanan untuk melakukan permohonan pemesanan barang. Pegawai gudang akan mencatat data pemesan dan barang yang ingin dipesan. Pegawai akan memeriksa terlebih dahulu apakah barang yang diminta berada di gudang atau tidak. Selain itu petugas juga harus terus berkoordinasi dengan pegawai untuk menanyakan status pemesanannya. Membutuhkan waktu yang lama untuk melakukan pemesanan barang sehingga proses bisnis menjadi tidak efisien. Alur layanan pemesanan barang saat ini dapat dilihat pada Gambar 1.

Dari permasalahan di atas, dapat ditangani dengan solusi membangun aplikasi pada smartphone untuk mempermudah petugas maupun pegawai Dinas Kebersihan dan Pertamanan dalam melakukan pemesanan barang. Sehingga diharapkan dengan diterapkannya solusi ini, Dinas Kebersihan dan Pertamanan Kota Surabaya dapat memecahkan masalah yang ada sebelumnya.

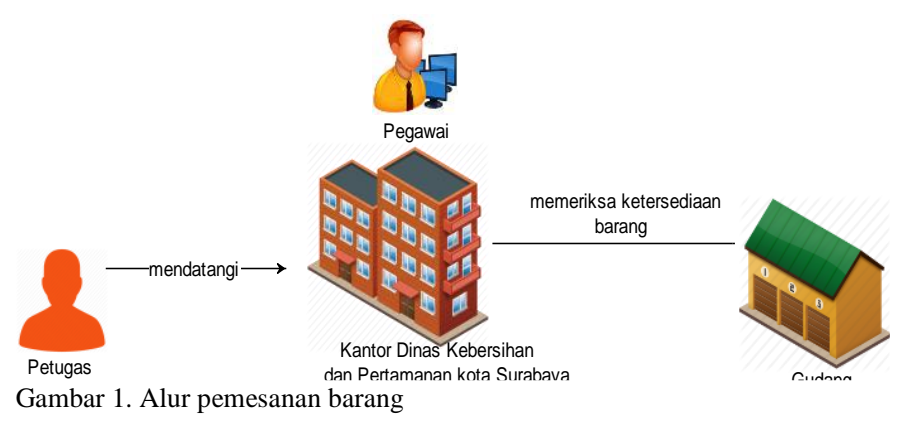

\section{TINJAUAN PUSTAKA}

\section{A. Android}

Android adalah salah satu sistem operasi open source berbasis Linux yang ada pada perangkat bergerak yang dioperasikan pada jenis smartphone [1]. Awalnya sistem operasi ini dikembangkan oleh Android, Inc dan kemudian pada tahun 2005 dibeli oleh perusahaan raksasa Google, Inc. Sistem operasi ini dirilis tahun 2007 dan saat ini merajai pasar penjualan perangkat bergerak, sehingga menggeser penjualan perangkat bergerak dengan sistem operasi yang lebih lama seperti Java, Symbian, dan Windows Mobile. Pengembangan aplikasi pada perangkat bergerak berbasis Android menggunakan bahasa pemrograman Java.

\section{B. JSON}

JSON adalah singkatan dari Java Script Object Notation, yaitu sebuah format untuk pertukaran data. Format ini dibuat berdasarkan bagian dari Bahasa Pemrograman Java Script, Standar ECMA-262 Edisi ke-3 Desember 1999. JSON 
merupakan format teks yang tidak bergantung pada bahasa pemrograman apapun karena menggunakan gaya bahasa yang umum digunakan oleh programmer keluarga $\mathrm{C}$ termasuk $\mathrm{C}$, C++, C\#, Java, JavaScript, Perl, Python [2].

\section{Volley Library}

Volley adalah sebuah library yang digunakan untuk membantu pertukaran data dari server dengan client. Volley membuat pertukaran data menjadi lebih mudah dan lebih cepat. Secara default semua jaringan volley menghasilkan asnchronous sehingga tidak perlu khawatir menggunakan AsyncTask [3]. Volley dilengkapi dengan banyak fitur, diantaranya adalah:

1. Antrian permintaan dan prioritas;

2. Efektif cache dan manajemen memori, dan;

3. Perluasan dan kustomisasi library untuk kebutuhan pengguna.

\section{D. $P H P$}

PHP (Hypertext Preprocessor) adalah bahasa script yang dapat diletakkan ke dalam HTML. PHP banyak digunakan untuk memrogram situs web dinamis. PHP memiliki beberapa kelebihan jika dibandingkan dengan bahasa pemrograman yang lain, diantaranya adalah [4]:

a. Dalam sisi pemahaman, PHP adalah bahasa scripting yang paling mudah karena memiliki referensi yang banyak.

b. PHP memiliki delapan tipe data, yaitu: Boolean, Integer, Float/Double, String, Array, Object, Resource, NULL

\section{ANALISIS DAN PERANCANGAN}

\section{A. Domain Permasalahan}

Kebersihan dan keindahan suatu kota adalah suatu hal yang harus diperhatikan. Jika di suatu kota terdapat kerusakan dan kesalahan infrastruktur, hendaknya pemerintah kota tersebut bergerak cepat untuk menanganinya. Tentunya dengan melewati prosedur-prosedur yang sudah ada. Seperti yang terjadi pada Kota Surabaya, khususnya Dinas Kebersihan dan Pertamanan. Dinas ini secara garis besar masih mengandalkan peralatan manual untuk menanggapi kerusakan dan kesalahan infrastruktur. Kerusakan infrastuktur yang biasanya terjadi adalah kurangnya tempat sampah di sekitar taman kota dan gerobak sampah di berbagai wilayah Surabaya yang sudah tidak layak pakai. Jika terdapat kerusakan suatu infrastruktur kota yang berhubungan dengan kebersihan dan pertamanan, petugas lapangan dari Dinas Kebersihan dan Pertamanan harus melaporkan dan memperbarui atau mengganti infrastruktur tersebut. Alur untuk mengganti infrastruktur yang rusak saat ini masih menggunakan cara manual. Petugas lapangan harus ke kantor terlebih dahulu untuk menginformasikan kerusakan infrastruktur. Selain itu, petugas diharuskan mengisi surat permintaan barang untuk perbaikan terlebih dahulu. Proses ini sudah sangat tidak efektif terlebih pegawai dinas harus mengecek ketersedian barang yang diminta di gudang. Jika barang yang diminta ada, petugas akan mencatat pemesanan barang yang diminta. Petugas lapangan menunggu barang yang dipesan sudah dikirim atau belum, dengan datang ke tempat yang membutuhkan infrastuktur tersebut. Koordinasi pengiriman barang antara petugas lapangan dan pegawai dinas masih menggunakan telepon maupun sms sehingga rawan akan miss-communication. Jika proses ini tetap dijalankan akan berdampak pada kesejahteraan masyarakat dimana pelayanan pemerintah yang lamban terhadap masalah kebersihan dan pertamanan kota.

Dari permasalahan di atas, solusi yang ditawarkan pada pembahasan tugas akhir ini adalah pembuatan aplikasi pada perangkat begerak. Aplikasi akan berjalan pada perangkat bergerak berbasis Android. Dengan solusi yang ditawarkan pada pembahasan tugas akhir ini diharapkan permasalahan yang ada dengan sistem yang ada saat ini dapat terselesaikan. Karena aplikasi ini dapat digunakan petugas dalam melakukan pemesanan barang sehingga petugas tidak perlu datang jauhjauh ke kantor. Selain itu petugas juga tidak perlu menunggu lama untuk mendapatkan barang yang dipesan. Petugas hanya melihat status pemesanan barang apakah sudah dikirim atau belum.

\section{B. Deskripsi Umum}

Berdasarkan permasalahan yang ada pada pembahasan domain permasalahan, solusi aplikasi yang ditawarkan adalah pembuatan aplikasi yang dipasang di smartphone. Aplikasi ini dapat melakukan pemesanan barang untuk penanganan masalah infrastruktur yang berkaitan dengan kebersihan dan pertamanan Kota Surabaya. Dengan menampilkan jumlah barang yang tersedia di gudang, pemesanan barang akan semakin cepat. Setelah memesan barang aplikasi juga akan menampilkan status pemesanan barang sampai status pemesanan selesai dikirim. Aplikasi yang akan dibuat juga dapat digunakan untuk melihat riwayat pemesanan barang. Untuk menangani pemesanan aplikasi juga dapat memanajemen pemesanan serta penggguna aplikasi.

\section{Aktor}

Aktor pada sistem yang akan dibuat di tugas akhir ini, aktor yang menjadi pengguna sistem adalah pegawai gudang di divisi administrasi gudang dan petugas Dinas Kebersihan dan Pertamanan di divisi turun jalan atau petugas lapanganPetugas Dinas Kebersihan dan Pertamanan menggunakan sistem yang dibangun pada perangkat bergerak berbasis Android yang digunakan untuk memesan barang dan pegawai gudang adalah administrator web yang menggunakan sistem aplikasi web untuk memanajemen pemesanan dan manajemen pengguna aplikasi.

\section{Kasus Penggunaan}

Berdasarkan analisis yang dilakukan maka didapatkan sembilan kasus penggunaan dalam sistem. Kasus penggunaan ini meliputi:

1. Pemesanan barang

2. Melihat status pemesanan

3. Melihat riwayat pemesanan

4. Memperbarui data diri

5. Manajemen pemesanan

6. Mengubah status pemesanan

7. Mengedit data pemesanan

8. Manajemen user

9. Melihat semua riwayat pemesanan

Arsitektur sistem dapat dilihat pada Gambar 2, sedangkan untuk kasus penggunaan dapat dilihat pada Gambar 3. 


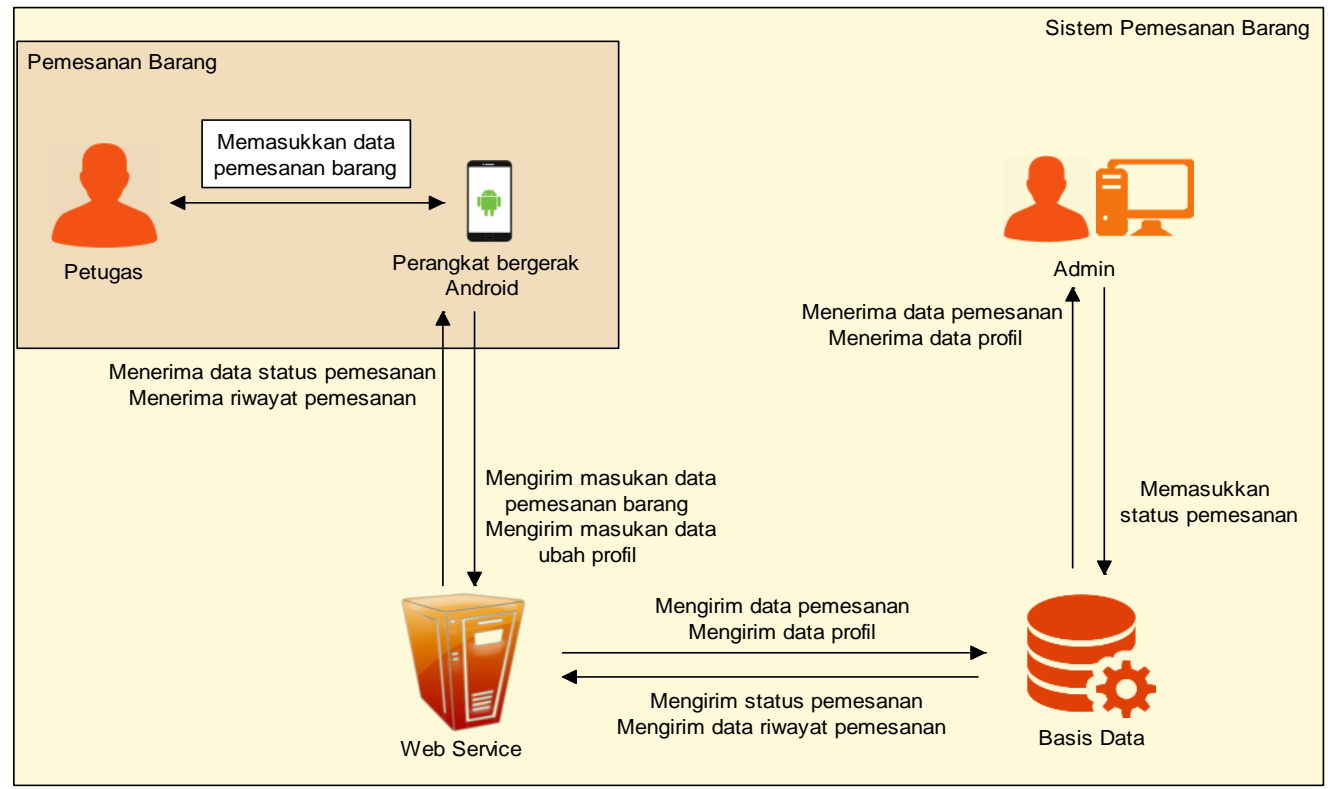

Gambar 2. Arsitektur sistem

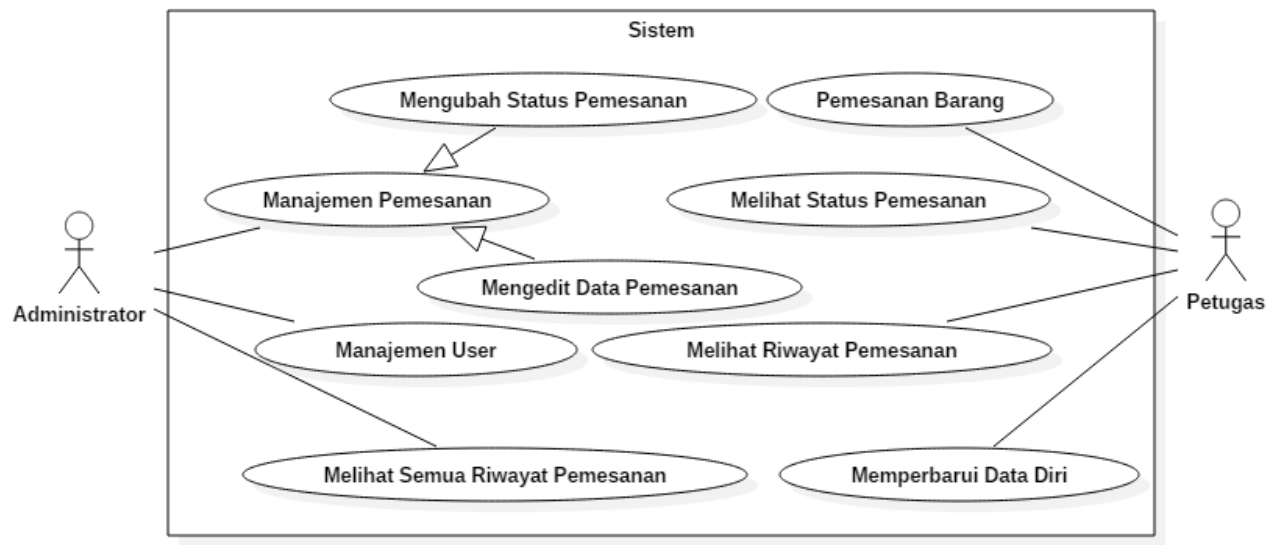

Gambar 3. Kasus penggunaan

\section{E. Perancangan Algoritma}

Algoritma yang digunakan dalam sistem meliputi algoritma memasukkan data pemesanan barang dan menampilkan status pemesanan:

\section{1) Algoritma Memasukkan Data Pemesanan}

Pengguna menekan tombol proses dimana pengguna harus memasukkan informasi pemesanan. Setelah semua terisi pengguna menekan tombol pesan, sistem akan menampilkan verifikasi pemesanan.

2) Algoritma Menampilkan Status Pemesanan

Sistem akan menampilkan pilihan pemesanan yang telah dilakukan, pengguna memilih salah satu pemesanan jika ingin melihat status pemesanannya. Setelah memilih, sistem akan menampilkan data pemesanan beserta status pemesanan berupa gambar secara real-time. Status pemesanan terdiri dari 4 macam yaitu 1 atau pesan, 2 atau ok, 3 atau dikirim, dan 4 atau selesai. Diagram alir algoritma menampilkan status pemesanan dapat dilihat pada Diagram 1.

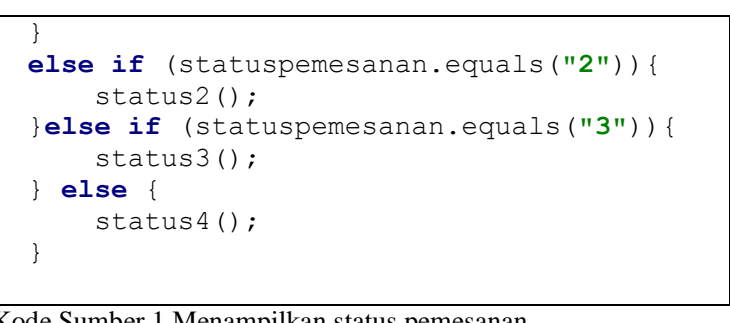

Kode Sumber 1 Menampilkan status pemesanan 


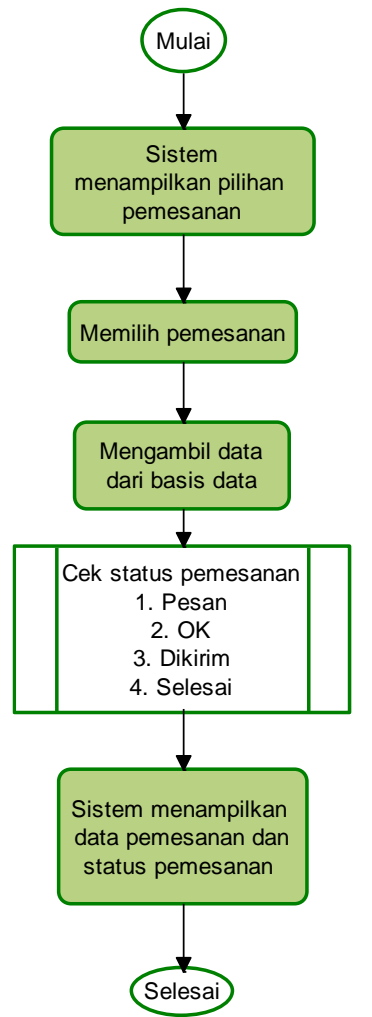

Diagram 1. Algoritma menampilkan status pemesanan

\section{IMPLEMENTASI}

\section{A. Lingkungan Implementasi}

Dalam merancang perangkat lunak ini digunakan beberapa perangkat pendukung yang terdiri dari perangkat keras dan perangkat lunak. Spesifikasi perangkat keras yang digunakan dalam membangun layanan pemesanan barang adalah sebagai berikut:

$\begin{array}{ll}\text { Jenis } & : \text { Komputer } \\ \text { Prosesor } & : \text { Intel } \AA \text { Core } \\ \text { Memori } & : 2 \text { i3 M330 @ 2,13GHz }\end{array}$

Sistem Operasi : Windows 8.1 (x64)

Perangkat lunak yang digunakan dalam membangun aplikasi layanan pemesanan barang adalah sebagai berikut:

- Android Studio digunakan untuk menyunting kode;

- StarUML 2.7.0 digunakan untuk membuat diagram kasus penggunaan, diagram aktivitas dan diagram kelas.

\section{B. Implementasi Antarmuka}

Antarmuka perangkat lunak dikembangkan menggunakan beberapa pustaka. Beberapa diantaranya adalah:

- Java dan PHP sebagai skrip bahasa utama;

- Volley Library sebagai alat bantu untuk pertukaran data;

- JSON sebagai format untuk pertukaran data, dan;

- Android SDK sebagai kakas bantu untuk Android.

Halaman utama aplikasi layanan pemesanan barang dapat dilihat pada Gambar 4. Terdapat 4 menu utama yaitu menu pesan barang yang berfungsi untuk memesan barang, menu lacak barang untuk melihat status pemesanan dan riwayat pemesanan, menu call center untuk informasi kantor, dan menu profil untuk mengubah data diri pada aplikasi.
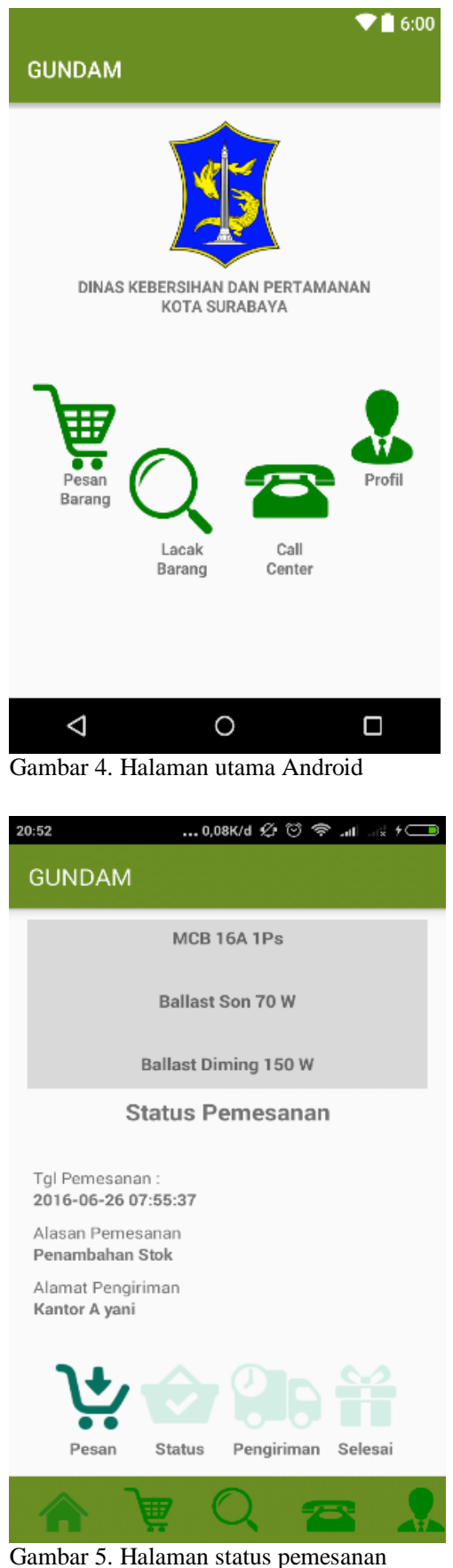

Halaman status pemesanan pada aplikasi dapat dilihat pada Gambar 5. Terdapat informasi pemesanan seperti, tanggal, alasan, alamat, barang, dan status pemesanan. Halaman riwayat pemesanan barang untuk web dapat dilihat pada Gambar 6 . Pada halaman ini terdapat beberapa pilihan pemesanan yang memiliki status selesai. Terdapat 1 tombol yaitu lihat detail pemesanan. Di halaman ini juga terdapat dua penyaring data pemesanan yang akan dilihat yaitu tahun dan bulan. 


\begin{tabular}{|c|l|l|l|l|l|l|l|l|}
\hline \multicolumn{2}{|c|}{ Pemesanan Barang Rivajat Pemesanan Barang } & & & & & & \\
\hline
\end{tabular}

Gambar 6. Halaman status pemesanan web

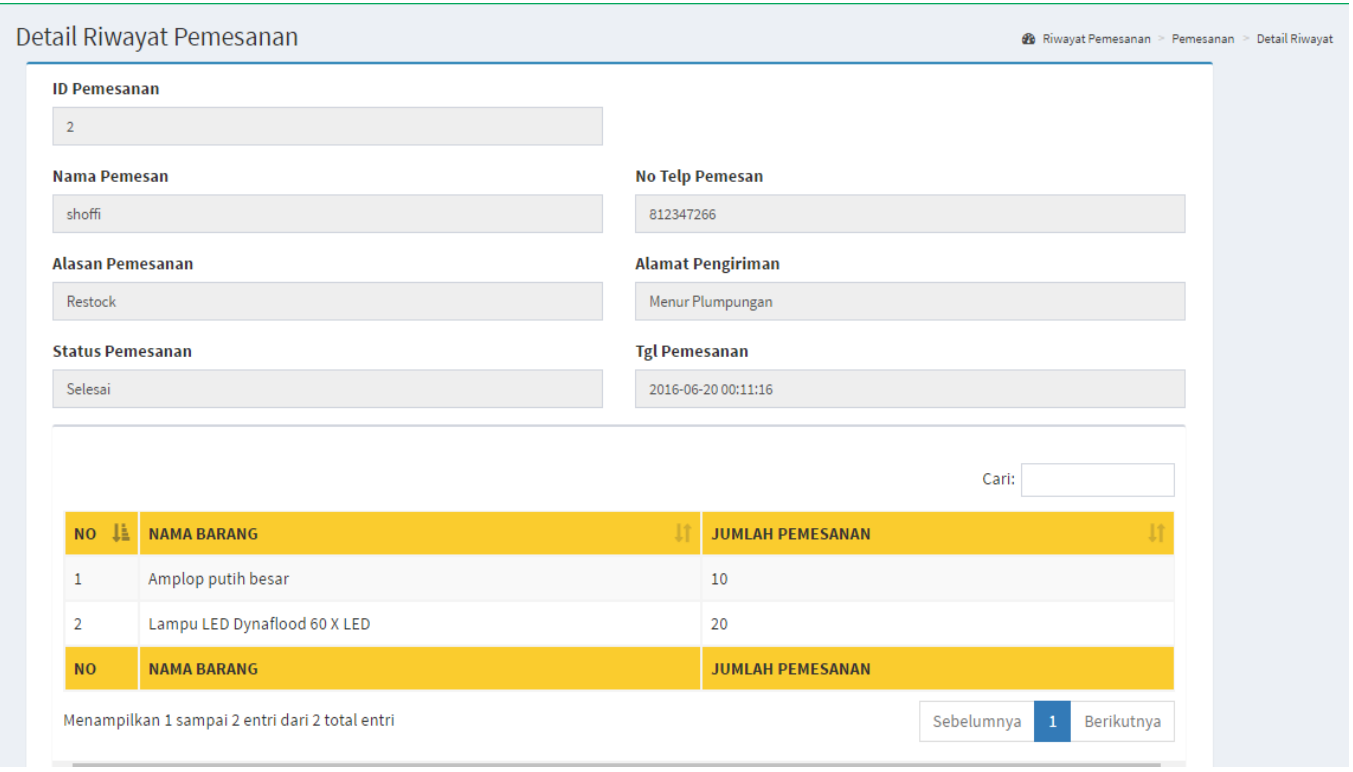

Gambar 7. Halaman detail riwayat pemesanan

Halaman detail riwayat pemesanan dapat dilihat pada Gambar 7. Pada halaman ini terdapat beberapa informasi yang dapat dilihat oleh pengguna yaitu id pemesanan, nama pemesan, no telepon pemesan, alasan pemesanan, alamat pengiriman, tanggal pemesanan, dan barang-barang yang dipesan.

\section{PENGUJIAN DAN EVALUASI}

\section{A. Skenario Pengujian}

Pengujian yang dilakukan adalah pengujian kebutuhan fungsionalitas. Pengujian fungsionalitas menggunakan metode kotak hitam (black box). Metode ini menekankan pada kesesuaian hasil keluaran sistem.

Pengujian dilakukan untuk mengetahui hasil dari masukan data dan keluaran data. Pada aplikasi Android, masukan data yang dibutuhkan data pemesanan. Keluaran yang diharapkan data pemesanan dapat tampil pada aplikasi dan dapat dilihat status pemesanannya dan dapat melihat riwayat pemesanan yang telah dilakukan. Pada aplikasi web, masukan data yang dibutuhkan adalah masukan manajemen pengguna aplikasi, manajemen data pemesanan, dan melihat rekap pemesanan. Keluaran yang diharapkan adalah data pemesanan dan rekap pemesanan barang.

Pengujian pertukaran data dan performa sistem juga akan dilakukan. Setelah itu pengujian juga dilakukan kepada responden yang memiliki peran yang sama atau hampir sama dengan pengguna sebenarnya.

\section{B. Evaluasi Pengujian}

Evaluasi yang diberikan meliputi evaluasi pengujian kebutuhan fungsional sebelumnya dan evaluasi pengujian performa sistem yang dilakukan sesuai dengan skenario dan prosedur yang telah didefinisikan sebelumnya. Berdasarkan data pada tabel Tabel 1, seluruh skenario pengujian yang telah dilakukan berhasil dan aplikasi berjalan dengan baik.

Tabel 1.

Evaluasi pengujian fungsionalitas

\begin{tabular}{clc}
\hline \hline ID & \multicolumn{1}{c}{ Nama } & Hasil \\
\hline TUC-001 & Pengujian Pemesanan Barang & Berhasil \\
TUC -002 & Pengujian Melihat Status Pemesanan & Berhasil \\
TUC -003 & Pengujian Melihat Riwayat Pemesanan & Berhasil \\
TUC -004 & Pengujian Memperbarui Data Diri & Berhasil \\
TUC -005 & Pengujian Melihat Status Pemesanan & Berhasil \\
TUC -006 & Pengujian Mengubah Status Pemesanan & Berhasil \\
TUC -007 & Pengujian Melihat Semua Riwayat & Berhasil \\
TUC -008 & Pemesanan & Pengujian Menambah User \\
TUC -009 & Pengujian Mengedit User & Berhasil \\
\hline \hline
\end{tabular}

Rangkuman mengenai hasil pengujian performa sistem dapat dilihat pada Tabel 2. Berdasarkan data pada tabel tersebut, pengujian yang dilakukan berhasil dan aplikasi berjalan dengan baik dan cepat. 
Tabel 2.

Evaluasi pengujian performa sistem

\begin{tabular}{|c|c|c|c|c|}
\hline No & Pengujian & Jaringan & Berhasil & Waktu \\
\hline 1 & $\begin{array}{l}\text { Menampilkan Kategori } \\
\text { Barang }\end{array}$ & 2G/EDGE & Ya & \pm 5 detik \\
\hline 2 & $\begin{array}{l}\text { Menampilkan Barang } \\
\text { dan Stok Barang }\end{array}$ & 2G/EDGE & Ya & \pm 5 detik \\
\hline 3 & Pemesanan Barang & 3G/HSDPA & Ya & \pm 5 detik \\
\hline 4 & $\begin{array}{l}\text { Menampilkan Status } \\
\text { Pemesanan }\end{array}$ & 2G/EDGE & Ya & \pm 8 detik \\
\hline 5 & $\begin{array}{l}\text { Menampilkan Riwayat } \\
\text { Pemesanan }\end{array}$ & 3G/HSDPA & Ya & \pm 5 detik \\
\hline
\end{tabular}

\section{KESIMPULAN}

Selama proses perancangan, implementasi, dan pengujian dapat diambil kesimpulan sebagai berikut:

1. Aplikasi Android layanan pemesanan barang berhasil dibangun dan dapat digunakan dimanapun dan kapanpun selama pengguna terhubung dengan jaringan internet.

2. Fitur pemesanan barang berdasarkan kategori barang berhasil dibangun dan menjadi solusi terhadap permasalahan pemesanan barang yang kurang efektif. Hal ini dapat dilihat dengan prosentase kuisioner jawaban $60 \%$ sangat setuju dan $40 \%$ setuju.

3. Fitur untuk melihat status pemesanan secara real time mempermudah pengguna untuk melihat status pemesanan yang telah dilakukan.

\section{DAFTAR PUSTAKA}

[1] "Android - Android Overview," [Online]. Available: http://www.openhandsetalliance.com/Android_overview.html. [Diakses 16 July 2014].

[2] “JSON," [Online]. Available: http://www.json.org/json-id.html. [Diakses 25 Januari 2014].

[3] G. Segato, "An Introduction to Volley," [Online]. Available: http://code.tutsplus.com/tutorials/an-introduction-to-volley--cms23800.

[4] Y. Purdianto, "Pengenalan PHP," [Online]. Available: http://yadicucuklauk.blogspot.co.id/2012/01/pengenalan-php.html. [Diakses 5 November 2015]. 